JIPS, Vol. 2 No. 1

Halaman: 52 - 63

Mei 2021
Jurnal Inovasi Pembelajaran di Sekolah

DOI: https://doi.org/10.51874/jips.v1i01.8

ISSN 2774-9363 (Cetak)

ISSN 2774-9746 (Online)
JIPS

Jurnal Inovasi Pembelajaran di Sekolah

\title{
Peran Kepala Sekolah dalam Meningkatan Prestasi Kerja Guru Melalui Pembuatan RPP Daring Menggunakan Metode Cooperative Script di SD Negeri Kemijen 02 Kota Semarang
}

\author{
Sri Sumarni \\ SD Negeri Kemijen 02 Kota Semarang
}

\begin{abstract}
Abstrak
Latar belakang masalah penelitian ini untuk mengetahui peran kepala sekolah dalam proses pelaksanaan pembuatan administrasi pembelajaran daring menggunakan metode cooperative script dan hasil peningkatan prestasi guru setelah melakukan pembuatan administrasi pembelajaran daring menggunakan metode cooperative script di SD Negeri Kemijen 02 Kota Semarang?Metode penelitian yang digunakan yaitu metode penelitian tindakan sekolah (PTS) dan data yang digunakan adalah prestasi guru dalam pembuatan administrasi daring terutama rencana pelaksanaan pembelajaran (RPP) melalui Metode Cooperative Script di SD Negeri Kemijen 02 Kota Semarang. Populasi dalam penelitian ini yaitu semua guru SD Negeri SD Negeri Kemijen 02 Kota Semarang yang berjumlah 8 orang.Hasil penelitian ini menunjukkan proses prestasi guru dalam pembuatan rencana pelaksanaan pembelajaran (RPP) melalui melalui Metode Cooperative Script dari siklus I hasil penelitian dan observasi komponen identitas $18 \%$, tujuan $31 \%$, kegiatan pembelajaran $17 \%$, penilaian $9 \%$ dan nilai rata rata semua guru $75 \%$ masuk pada kriteri cukup sedangkan pada perbaikan siklus II, mengalami peningkatan dalam pembuatan administrasi daring terutama rencana pelaksanaan pembelajaran (RPP) komponen identitas 20\%, tujuan 36\%, pelaksanaan pembelajaran $21 \%$ sedangkan penilaian $11 \%$ dan rata rata $87 \%$ dari semua guru mengalami kenaikan $12 \%$.Hasil pembuatan administrasi daring melalui metode cooperative script yaitu munculnya inovasi-inovasi baru bagi guru-guru SD Negeri Kemijen 02. Kepercayaan diri guru semakin meningkat dalam mendiskripsikan dan pemaparan didepan teman teman guru lainnya. Metode cooperative script mampu merubah perilaku guru-guru SD Negeri Kemijen 02 secara signifikan, yang akhirnya berdampak pada perubahan sikap dan perilaku dalam proses pembuatan administrasi terutama RPP yang berdampakpula terhadap prestasi kerja guru.
\end{abstract}

Kata Kunci : Prestasi Kerja Guru

\section{Abstract}

The background of this research problem is to determine the role of the principal in the implementation process of making online learning administration using the cooperative script method and the results of increasing teacher achievement after making online learning administration using the cooperative script method in SD Negeri Kemijen 02 Semarang City?The research method used is the school action research method (PTS) and the data used is the teacher's achievement in making online administration, especially the lesson plan (RPP) through the Cooperative Script Method at SD Negeri Kemijen 02 Semarang City. The population in this study were all 8 teachers of SD Negeri Kemijen 02 Semarang City.The results of this study indicate the process of teacher achievement in making lesson plans (RPP) through the Cooperative Script Method from the first cycle of research results and observation of the identity component of $18 \%$, objectives $31 \%$, learning activities $17 \%$, assessment of $9 \%$ and the average score of all teachers. $75 \%$ entered into sufficient criteria while in the second cycle improvement, there was an increase in making online administration, especially the learning implementation plan (RPP), the identity component was $20 \%$, the goal was $36 \%$, the implementation of learning was $21 \%$ while the assessment was $11 \%$ and an average of $87 \%$ of all teachers experienced an increase of $12 \%$.The results of making online administration through the cooperative script method are the emergence of new innovations for SD Negeri Kemijen 02 teachers. Teacher confidence has increased in describing and presenting in front of other teacher friends. The cooperative script method is able to significantly change the behavior of SD Negeri Kemijen 02 teachers, which in turn has an impact on changes in attitudes and behavior in the administration-making process, especially lesson plans which have an impact on teacher work performance.

Keywords: Teacher Work Achievement 


\section{PENDAHULUAN}

Peroblematika pembelajaran daring ini tidak hanya dialami oleh peserta didik, tetapi dengan masih mewabahnya covid-19 sampai dengan akhir tahun ajaran yang mengharuskan guru-guru membuat soal ujian atau penilaian akhir Tahun Pelajaran 2019/2020 dalam bentuk daring, ini juga hal baru bagi guru-guru di Indonesia, dengan motivasi yang tinggi akhirnya guru berhasil tetap melakukan Penilaian Akhir Semester (PAS) dengan baik dan tingkat keikutsertaan anak yang sesuai dengan yang diharapkan.

Peraturan walikota Semarang nomor 57 tahun 2020 tentang pelaksanaan pembatasan kegiatan masyarakat dalam rangka pencegahan pengendalian corona virus disease 2019 (Covid-19) kota Semarang . Dengan adanya perintah belajar dari rumah tersebut tidaklah serta merta dapat diterima dan dilakukan masyarakat kota Semarang, terlebih karena masih terbatasnya kemampuan teknologi komunikasi masyarakat dan juga biaya yang banyak harus dikeluarkan untuk pembelian paket internet bahkan ada yang harus membeli handphone berbasis Android baru untuk menunjang pembelajaran Daring (dalam jaringan) yang dilakukan oleh masing-masing sekolah.

Di sinilah letak peran signifikan seorang Kepala Sekolah untuk tetap menjalankan kepemimpinannya dengan baik di tengah situasi krisis seperti ini. Kepala sekolah dituntut menerapkan “manajemen krisis", yaitu proses mempersiapkan dan mengelola situasi darurat atau tidak terduga yang mempengaruhi peserta didik, guru, staf, dan pemangku kepentingan. Ini merupakan komponen penting dari Public Relation (PR). Ini berbeda dari manajemen risiko, yang mengharuskan kepala sekolah untuk menilai potensi ancaman dan menemukan cara terbaik untuk menghindari ancaman tersebut. Dalam manajemen krisis, ancaman ini sudah terjadi dan harus dihadapi. Ancaman atau krisis yang sedang dihadapi saat ini tidak sepenuhnya buruk bagi sekolah. Sebaliknya, ia justru bisa memotivasi sekolah untuk menjadi lebih baik di masa depan. Contohnya, banyak sekolah yang pada akhirnya melakukan transformasi digital dengan menggunakan aplikasi berbasis web untuk memudahkan proses pembelajaran, rapat, dan koordinasi manajerial ketika harus bekerja dari rumah.

Kepala sekolah sebagai seorang supervisor mempunyai tanggung jawab untuk peningkatan kemampuan guru dalam mengelola kegiatan pembelajaran di sekolah serta mempunyai peranan yang sangat penting terhadap perkembangan dan kemajuan sekolah. Oleh karena itu, kepala sekolah harus melakukan supervisi secara baik dan benar sesuai dengan prinsip-prinsip dan teknik serta pendekatan yang tepat. Pembinaan-pembinaan yang dilakukan oleh kepala sekolah kepada guru dapat meningkatkan kinerja dan dedikasi guru dalam pendidikan. Tugas seorang supervisor adalah membantu, mendorong dan memberikan keyakinan kepada guru bahwa proses belajar mengajar dapat memberikan pengembangan berbagai pengalaman, pengetahuan, sikap dan keterampilan guru serta proses belajar mengajar yang dilakukan oleh guru tersebut harus dibantu secara profesional sehingga guru dapat 
berkembang dalam pekerjaannya yaitu untuk meningkatkan efektivitas dan efisiensi proses belajar mengajar.

Kepala sekolah sebagai seorang supervisor mempunyai tanggung jawab untuk peningkatan kemampuan guru dalam mengelola kegiatan pembelajaran daring di sekolah serta mempunyai peranan yang sangat penting terhadap perkembangan dan kemajuan sekolah. Di dalam proses belajar mengajar agar pembelajaran efektif maka diperlukan suatu media yang sesuai dengan karakter peserta didik, mata pelajaran yang disampaikan, suasana dan prasarana penunjang. Dengan perangkat pembelajaran yang baik akan menuntun peserta didik untuk dapat meningkatkan hasil belajar dengan baik. Untuk itu pada pembelajaran daring diperlukan pembelajaran yang menarik dan memudahkan peserta didik untuk memahami proses pengolahan suatu makanan.

Media pembelajaran adalah saluran atau perantara yang digunakan untuk menyampaikan pesan atau materi ajar. Media sangat diperlukan dalam pembelajaran sebagai alat penyampaian informasi dan pesan dari guru kepada peserta didik. Pembelajaran yang baik dan berlangsung lancar memerlukan media pembelajaran yang baik dan sesuai dengan kondisi kelas. Pembelajaran daring membutuhkan media yang mengandung unsur gerak, oleh karena itu, video pembelajaran merupakan salah satu media yang sesuai untuk menampilkan tahap-tahap dalam proses pembelajaran daring yang disesuaikan dengan materi pembelajaraan secara detail dan terperinci. Media video pembelajaran adalah media atau alat bantu mengajar yang berisi pesan-pesan pembelajaran. Video sebagai media audio visual dan mempunyai unsur gerak akan mampu menarik perhatian dan motivasi peserta didik dalam melaksanakan kegiatan pembelajaran.

Berdasarkan observasi awal melalui supervisi individu yang dilakukan kepala sekolah SD Negeri Kemijen 01yang juga sebagai peneliti terlihat permasalahan guru di SD Negeri Kemijen 01 dalam pembelajaran daring ini adalah media video. Selama ini guru dalam memberikan tugas kepada peserta didik yang berupa video hasil dari downloud dari internet juga dalam pemberian tugas hanya mengandalkan video dari kelompok guru kecamatan Semarang Timur yang diunduh melalui gruop media sosial whattshap hal ini sangat mempengaruhi ketergantungan guru di SD Negeri Kemijen 01pada konten orang lain. Peneliti menganggap perlu dilakukan penelitian video pembelajaran dan peneliti akan melakukan penelitian dengan judul “ Peningkatan Kinerja Guru Dalam Pembuatan Video Pembelajaran Daring Melalui Supervisi Individual SD Negeri Kemijen 01 Kota Semarang”

\section{KAJIAN PUSTAKA}

\section{Peran Kepala Sekolah}

Kepala sekolah adalah guru yang mendapatkan tugas tambahan sebagai kepala sekolah, mempunyai kemampuan untuk memimpin segala sumber daya yang ada di suatu sekolah, sehinga dapat 
didayagunakan secara maksimal untuk mencapai tujuan bersama. Menurut Sudarwan Danim (2010:145), kepala sekolah adalah guru yang mendapat tugas tambahan sebagai kepala sekolah. sementara menurut Daryanto (2011:136), kepala sekolah adalah pemimpin pada suatu lembaga pendidikan. kepala sekolah ialah pemimpin yang proses kehadiranya dapat dipilih secara langsung, ditetapkan oleh yayasan, atau ditetapkan oleh pemerintah. Kepala sekolah adalah seorang tenaga fungsional guru yang diberi tugas untuk memimpin suatu sekolah di mana terjadi interaksi antara guru yang memberi pelajaran dan murid yang menerima pelajaran Wahjosumijdo (2003:83).

Kepemimpinan kepala sekolah kemampuan kepala sekolah untuk memimpin, menggerakan, melakukan koordinasi, atau mempengaruhi para guru dan segala sumber daya yang ada di sekolah sehingga dapat di dayagunakan secara maksimal untuk mencapai tujuan yang telah ditetapkan.

Kepala sekolah berasal dari dua kata yaitu "kepala" dan "sekolah" kata kepala dapat diartikan ketua atau pemimpin dalam suatu organisasi atau sebuah lembaga. sedangkan sekolah adalah sebuah lembaga di mana menjadi tempat menerima dan memberi pelajaran. jadi secara umum kepala sekolah dapat diartikan pemimpin sekolah atau suatu lembaga di mana tempat menerima dan memberi pelajaran. Khususnya berkaitan dengan kualifikasi yang dibutuhkan agar mampu menjalankan tugas dan tanggung jawab besarnya dalam memimpin sekolah, Muwahid shulhan (2013:11)

Kepala sekolah adalah jabatan fungsional yang diberikan oleh lembaga yang menaungi sekolah, bisa yayasan, kementrian pendidikan nasional, kementrian agama atau yang lainya, baik melalui mekanisme pemilihan, penunjukan maupun yang lainnya kepada seseorang. menetapkan kepala sekolah oleh lembaga-lembaga ini tentu dengan pertimbangan matang,

Berdasarkan beberapa pendapat tersebut, secara garis besar, dapat disimpulkan bahwa kepala sekolah adalah seorang guru yang mempunyai kemampuan untuk memimpin segala sumber daya yang ada disuatu sekolah, sehingga dapat digunakan secara maksimal untuk mencapai tujuan bersama.

Peran Kepala Sekolah Dalam Pembinaan Prestasi Kerja Guru

Menurut Wahjosumijdo (2003:80-82), Peran dapat diartikan sebagai prilaku yang diatur dan diharapkan dari seseorang dalam posisi tertentu. pemimpin di dalam organisasi/lembaga mempunyai perannan, setiap pekerjaan membawa serta harapan bagai mana penanggung peran berperilaku. kepala sekolah yang berhasil apa bila mereka memahami keberadaan sekolah sebagai organisasi yang kompleks dan unik, serta mampu melaksanakan peran kepala sekolah sebagai seorang yang diberi tanggung jawab untuk memimpin sekolah. Berdasarkan rumusan di atas menunjukan betapa pentingnya perannan kepala sekolah dalam mengerakan kehidupan sekolah untuk mencapai tujuan. Menurut E. Mulyasa kepala sekolah mempunyai 7 peranan yaitu:

1. Kepala Sekolah sebagai Educator (Pendidik)

2. Kepala Sekolah sebagai Manajer 


\section{Kepala Sekolah sebagai Administrator}

4. Kepala Sekolah sebagai Supervisor

5. Kepala Sekolah sebagai Leader (Pemimpin)

6. Kepala Sekolah sebagai Inovator

7. Kepala Sekolah sebagai Motivator

\section{Prestasi Kerja Guru}

Guru adalah profesi dimana seseorang menanamkan nilai-nilai kebijakkan ke dalam jiwa manusia. guru adalah sosok yang mulia seorang yang berdiri di depan, teladan tutur kata dan tingkah laku, yang dipundaknya melekat tugas sangat mulia menciptakan generasi yang paripurna. guru adalah salah satu tiang utama bangsa dan negara. guru juga yang menjadi ujung tombak dalam sebuah perubahan. harapan akan munculnya sebuah generasi yang tanguh bagi sebuah bangsa atau negara dipercaya oleh masyarakat luas akan lahir dari sentuhan tangan para guru Hamka Abdul Aziz (19-21).

Menurut Siti Suwa Dahrimang (2011:1-4) guru adalah sosok manusia yang senantiasa memberi contoh yang baik dalam segala aktifitas kehidupan anak didik baik di luar kelas maupun di dalam kelas, guna mencapai tujuan hidup yang lebih bermartabat. guru adalah manusia yang rela menyumbangkan sebagian waktunya untuk berbagi ilmu kepada semua anak didiknya bahkan kepada seluruh lapisan masyarakat. guru bertanggung jawab terhadap perkembangan pengajar dengan tetap berusaha mengupayakan seluruh potensinya, baik potensi apektif, potensi kognitif, maupun potensi psikomotorik demi kelangsungan sebuah pendidikan. guru juga berarti orang dewasa yang bertanggung jawab memberikan bantuan kepada anak didik dalam perkembangan jasmani dan rohani, agar mencapai tingkat kedewasaan serta mampu berdiri sendiri dalam memenuhi segala tugas dan kewajiban sabagai mahluk hidup.

Guru merupakan manusia yang paling bertanggung jawab mencerdaskan kehidupan anak didik, mengubah segala bentuk perilaku dan pola pikir manusia. membebaskan manusia dari belenggu kebodohan. pribadi susila yang cakap adalah yang senantiasa menjadi harapan pada setiap anak didik. oleh sebab itu dengan penuh dedikasi dan loyalitas yang tinggi guru berusaha memberi bimbingan dan pembinaan agar kelak anak didik yang mereka bina dapat menjadi tumpuan keluarga, bangsa dan agama. Jadi pada dasarnya guru harus bertanggung jawab atas segala sikap, tingkah laku dan perbuatannya dalam rangka membina jiwa dan watak anak didik.

Guru bukan hanya yang mampu berdiri di depan kelas, siapapun di muka bumi ini dapat disebut guru. apapun dan siapapun yang telah memberikan sebuah ajaran kebijakan dia adalah guru. dapat mengubah seorang yang jahat menjadi orang yang baik juga dapat disebut guru. guru tetaplah merupakan titik sentral dalam keterlaksanaan pendidikan. tanpa guru proses pendidikan tidak akan 
terarah. manusia tidak akan dapat membedakan mana yang baik dan mana yang buruk, karena mereka tidak mendapat bimbingan dari guru. Dapat disimpulkan bahwa guru merupakan model, teladan atau contoh yang ditiru oleh pengajar, guru harus mampu mengarahkan pengajar ke arah yang lebih baik dengan keahlian yang dimilikinya, disamping itu guru memiliki tanggung jawab untuk mencerdaskan pengajar untuk menuju pencapaian pendidikan .

\section{RPP}

Kegiatan proses belajar mengajar harus menggunakan rencana pelaksanaan pembelajaran (RPP) agar proses belajar mengajar memenuhi syarat dalam mengajar. Sebagaimana dijelaskan oleh Nanang Hanafiah dan Cucu Suhana (2012 :120,) Rencana pelaksanaan pembelajaran adalah rencana yang menggambarkan prosedur dan pengorganisasian pembelajaran untuk mencapai suatu kompetensi dasar yang ditetapkan dalam standar isi dan dijabarkan dalam silabus. Lingkup rencana pembelajaran paling luas mencangkup satu kompotensi dasar yang terdiri atas 1 indikator atau beberapa indikator untuk satu kali pertemuan atau lebih. guru merancang penggalan RPP untuk setiap pertemuan yang disesuaikan dengan penjadwalan di satuan pendidikan .

Sebagaimana dalam permendikbud No 22 (2016 hlm.6) Rencana Pelaksanaan Pembelajaran (RPP) adalah rencana kegiatan pembelajaran tatap muka untuk satu pertemuan atau lebih. RPP dikembangkan dari silabus untuk mengarahkan kegiatan pembelajaran pengajar dalam upaya mencapai Kompetensi Dasar (KD). Setiap pendidik pada satuan pendidikan berkewajiban menyusun RPP secara lengkap dan sistematis agar pembelajaran berlangsung secara interaktif, inspiratif, menyenangkan, menantang, efisien, memotivasi pengajar untuk berpartisipasi aktif, serta memberikan ruang yang cukup bagi prakarsa, kreativitas, dan kemandirian sesuai dengan bakat, minat, dan perkembangan fisik serta psikologis pengajar. RPP disusun berdasarkan KD atau subtema yang dilaksanakan kali pertemuan atau lebih. Berdasarkan dua teori di atas dapat disimpulkan bahwa RPP adalah rencana kegiatan untuk satu pertemuan atau lebih untuk mencapai suatu kompetensi.

\section{Prinsip-prinsip RPP}

Selain definisi di atas RPP pun mempunyai prinsip-prinsip seperti yang di kemukakan oleh Nanang Hanafiah dan Cucu Suhana (2012:122) yaitu :

1) Memperhatikan perbedaan individu pengajar RPP disusun dengan memperhatikan perbedaan jenis kelamin, kemampuan awal, tingkat intelektual ,minat, motivasi belajar, bakat, potensi, kemampuan sosial, emosi, gaya belajar, latar belakang budaya, norma, nilai, dan atau lingkungan pengajar.

2) Mendorong partisipasi aktif pengajar Proses pembelajaran dirancang dengan berpusat pada pengajar untuk mendorong motivasi, minat, aktivitas, inisiatif, inspirasi, kemandirian dan semangat belajar. 
3) Mengembangkan membaca dan menulis proses pembelajaran dirancang untuk mengembangkan kegemaran membaca, pemahamaan beragan bacaan, dan berkreasi dalam beragan bentuk tulisan

4) Memberikan umpan balik dan tindak lanjut. RPP Memuat rancangan program pemberian umpan balik positif ,penguatan, pengayaan, dan remedy.

5) Keterkaitan dan keterpaduan RPP disusun dengan memperhatikan keterkaitan dan keterpaduanantara SK,KD,materi pembelajaran, kegiatan pembelajaran,indikator pencapaian kompetensi,penilaian dan sumber belajar dalam satukeutuhan pengalaman belajar.RPP disusun dengan mengakomodasikan pembelajaran tematik ,keterpaduan lintas mata pelajaran,lintas aspek belajar, dan keragaman budaya.

6) Menerapkan teknologi informasi dan komunikasi RPP disusun dengan mempertimbangkan penerapan teknologi informasi dan komunikasi secara terintegrasi ,sistematis, dan efektifsesuai dengan situasi dan komdisi.

Sebagaimana dalam Permendikbud No 22 (2016 hml. adalah Prinsip Penyusunan RPP dalam menyusun RPP hendaknya memperhatikan prinsip-prinsip sebagai berikut:

1) Perbedaan individual pengajar antara lain kemampuan awal, tingkat intelektual, bakat, potensi, minat, motivasi belajar, kemampuan sosial, emosi, gaya belajar, kebutuhan khusus, kecepatan belajar, latar belakang budaya, norma, nilai, dan/atau lingkungan pengajar.

2) Partisipasi aktif pengajar.

3) Berpusat pada pengajar untuk mendorong semangat belajar, motivasi, minat, kreativitas, inisiatif, inspirasi, inovasi dan kemandirian.

4) Pengembangan budaya membaca dan menulis yang dirancang untuk mengembangkan kegemaran membaca, pemahaman beragam bacaan, dan berekspresi dalam berbagai bentuk tulisan.

5) Pemberian umpan balik dan tindak lanjut RPP memuat rancangan program pemberian umpan balik positif, penguatan, pengayaan, dan remedi.

6) Penekanan pada keterkaitan dan keterpaduan antara $\mathrm{KD}$, materi pembelajaran, kegiatan pembelajaran, indicator pencapaian kompetensi, penilaian, dan sumber belajar dalam satu keutuhan pengalaman belajar.

7) Mengakomodasi pembelajaran tematik-terpadu, keterpaduan lintas mata pelajaran, lintas aspek belajar, dan keragaman budaya.

Penerapan teknologi informasi dan komunikasi secara terintegrasi, sistematis, dan efektif sesuai dengan situasi dan kondisi

\section{Metode Pembelajaran Cooperative Script}

Slavin mengatakan bahwa salah satu metode pembelajaran yang dapat meningkatkan daya ingat pengajar adalah pembelajaran dengan metode cooperative script. Cooperative script adalah metode 
pembelajaran dimana pengajar berkerja berpasangan dan mengikhtisarkan bagian-bagian dari materi yang dipelajari. Metode cooperative script membuat pengajar dapat terlibat aktif di dalam proses pembelajaran. Sehingga metode cooperative script dapat melatih pengajar untuk mengingat materi yang telah dipelajari, saling bekerja sama serta dapat terlibat secara aktif di dalam proses pembelajaran, Riyanto,( 2009:284).

Teknik pembelajaran cooperative script adalah suatu metode belajar di mana pengajar bekerja secara berpasangan dan secara bergantian menyampaikan hasil ringkasan materi yang dipelajari. Aktivitas belajar seperti ini dapat membuat pengajar lebih aktif dalam proses pembelajaran dan membuat pengajar saling bekerja sama dan bertanggung jawab terhadap tugas yang diberikan. Pendapat hampir sama dikemukakan oleh Hamzah B. Uno dan Nurdin Mohamad, skrip kooperatif merupakan metode belajar di mana pengajar bekerja berpasangan dan bergantian menyampaikan hasil ringkasan dari materi pelajaran yang diberikan pendidik.

\section{Metode Pembelajaran Cooperative Script}

Metode Cooperative Script merupakan salah satu metode belajar kooperatif yang dikemukakan oleh Danserau dan kawan-kawan pada tahun 1985 (Riyanto, 2009:284). Metode belajar dengan cara ini adalah siswa bekerja kelompok kemudian kelompok tersebut bergantian membacakan ikhtisar bagianbagian dari bacaan yang dipelajari. Pembelajaran kooperatif ini memiliki perberbedaan dengan metode pembelajaran yang lain yang dapat dilihat dari proses pembelajaran yang lebih menekankan kepada proses kerja sama dalam kelompok. Tujuan yang ingin dicapai tidak hanya kemampuan akademik dalam pengertian penguasaan bahan pelajaran, tapi juga adanya unsur kerja sama untuk penguasaan materi tersebut. Kelebihan metode pembelajaran kooperatif bila dibanding dengan metode pembelajaran ceramah yang masih bersifat tradisional adalah memberi peluang pengajar untuk mengemukakan pendapat dan membahas suatu pandangan atau pengalaman yang diperoleh pengajar pada saat berdiskusi, serta belajar dengan cara bekerja sama menyelesaikan masalah dalam suatu kelompok. Berikut rincian mengenai tahapan metode Cooperative Script. Suprijono (2011: 126)

a. Membentuk kelompok Siswa membentuk kelompok. Pembentukan kelompok dapat dibantu/ditentukan oleh guru. Kemudian guru membagi kelompok yang ada untuk berpasangan dan menentukan peran masing-masing kelompok. Peran kelompok sebagai pembaca dan pendengar.

b. Membaca Setiap siswa akan menerima bacaan dari guru. Kemudian, siswa membaca dan memahami isi bacaan tersebut. Ketika membaca teks siswa menandai bagian-bagian yang penting dalam bacaan.

c. Diskusi Diskusi dilakukan oleh siswa di dalam kelompok masing-masing. Siswa mendiskusikan gagasan utama yang ditemukan dalam teks yang telah dibaca. Langkah selanjutnya adalah membuat 
script. Script berisi ringkasan hasil diskusi setiap kelompok dengan berisikan butir-butir gagasan utama yang di dapat dari bacaan.

d. Presentasi Membacakan hasil diskusi yang diwakili oleh satu orang siswa pada setiap peran kelompok. Kesempatan pertama diberikan pada kelompok pembaca. Kelompok pembaca membacakan script hasil diskusi di depan kelas dan kelompok pendengar menanggapi. Kemudian dilanjutkan dengan pasangan kelompok lain yang juga akan melakukan kegiatan yang sama. Pasangan kelompok selanjutnya diharapkan akan memberikan hasil yang lebih baik

e. Refleksi Pada saat kegiatan refleksi ini, guru dapat memberikan kritik mengenai jalannya proses pembelajaran. Dalam refleksi ini, guru melengkapi jawaban yang kurang tepat dari hasil semua presentasi.

\section{METODE PENELITIAN}

Metode penelitian adalah cara yang digunakan oleh peneliti dalam mengumpulkan data penelitiannya.1 Metode yang digunakan dalam penelitian ini adalah penelitian tindakan sekolah. Penelitian menunjukkan pada suatu kegiatan mencermati suatu obyek dengan cara menggunakan cara dan aturan metodologi tertentu untuk memperoleh data atau informasi yang bermanfaat dalam meningkatkan mutu suatu hal yang menarik minat dan penting bagi peneliti. Tindakan : menujukkan pada suatu obyek kegiatan yang sengaja dilakukan dengan tujuan tertentu. Dalam penelitian berbentuk rangkaian siklus kegiatan untuk siswa. Sekolah : dalam hal ini tidk terikat pada pengertian ruang kelas, tetapi dalam pengertian yang lebih spsifik, yakni sekelompok siswa yang dalam waktu yang sama, menerima pelajaran yang sama dari guru yang sama pula.

\section{Subjek dan Objek Penelitian}

Penelitian dilakukan terhadap 6 Guru kelas, 1 guru PJOK dan 1 guru PAI. Kegiatan yang menjadi setting Penelitian Tindakan Sekolah adalah prestasi guru SD Negeri Kemijen 02 dalam pembuatan administrasi pembelajaran daring terutama RPP menggunakan metode cooperative Script menghadapi pandemi covid-19

\section{Instrumen tes}

Instrumen tes digunakan untuk mengungkapkan data tentang prestasi guru melalui metode cooperative Script pada prestasi guru. Untuk mengetahui tingkat prestasi dalam penggunaan metode cooperative Script digunakan alat ukur berupa tes performansi penggunaan metode cooperative Script. Tes ini menggunakan pembuatan RPP daring dengan menggunakan metode cooperative Script sehingga sesuai dengan tingkat perkembangan guru untuk berani tampil dalam menyampaikan hasil pembelajaran melalui diskusi. 
Penilaian hasil dalam kompetensi dasar penngunaan metode cooperative Script dengan metode yang sesuai dengan indikator pembelajaran yang harus dicapai guru, yaitu (1) mampu penggunaan metode cooperative Script dan ketrampilan penggunaan metode cooperative Script yang baik, dan (2) mampu dalam pembuatan administrasi pembelajaran daring terutama RPP menggunakan metode cooperative Script dengan baik.

\section{HASIL DAN PEMBAHASAN}

\section{Hasil}

\section{Siklus I}

Berdasarkan hasil pengamatan dan respon pada siklus I diketahui bahwa hasil yang diperoleh belum memenuhi keinginan peneliti dalam penerapan Metode cooperative Script dalam pembelajaran. Meskipun dalam pelaksanaan pembuatan administrasi terutama RPPdengan menggunakan Metode cooperative Script guru di SD Negeri Kemijen 02 Kota Semarang terkendala dengan teori teori yang mendukung dalam komponen RPP, hal ini terlihat pada saat guru berdiskusi masih tergantung dengan contoh yang diberikan oleh peneliti maupun teman sebaya. Pada kegiatan siklus I kemajuan dalam prestasi dalam pembuatan RPP tersebut dibandingkan dengan pelaksanaan kegiatan yang sama sebelum ada penelitian. Perbaikan yang sangat mendesak yaitu pengertian teori tentang komponen komponen yang terkandung dalam RPP. Melihat hasil kinerja pada siklus I yang kurang memenuhi maka diperlukan perbaikan pada tindakan siklus II. Kelemahan dan kekurangan yang terjadi selama siklus I maka akan dicarikan solusi dan akan dilakukan perbaikan-perbaikan dalam melakukan siklus II.

\section{Siklus II}

Setelah dilakukan tindakan pada siklus II sebagaimana yang tercantum pada BAB III, diperoleh hasil penerapan metode cooperative Script dalam pembelajaran pada sklus II sebagai berikut:

Pada saat melakukan diskusi dan pemaparan dalam pembuatan administrasi RPP dengan menggunakan metode cooperative script seluruh guru melakukan dengan senang tanpa adanya rasa takut maupun rasa cepat bosan. Antusias dalam melaksanakan kegiatan tersebut guru memahami cara pembuatan RPP daring terlihat keterlibatan guru dalam melakukan mandiri maupun kelompok. Guru dalam pembuatan administrasi RPP dengan menggunakan metode cooperative script terlibat baik dari pemahaman maupun ketrampilan. Dalam kerjasama kelompok banyak peningkatan baik saat bertanya maupun saat melakukan penerapan media pembelajaran visual. Prestasi guru dalam pembuatan administrasi RPP dengan menggunakan metode cooperative script meningkat secara signifikan.

\section{Pembahasan Hasil Penelitian}

1. Memperhatikan data yang diperoleh tampak bahwa dalam penelitian tindakan sekolah di SD Negeri Kemijen 02 Kota Semarang dengan penerapam metode cooperative script sesuai dengan harapan. 
Hal ini terbukti dengan indikator kinerja yang telah ditetapkan pada akhir siklus tercapai. Selama pelaksanaan penelitian, dari siklus pertama ke siklus berikutnya selalu terjadi peningkatan, baik dalam hal perubahan guru dalam menjalankan tugas pembutan administrasi daring terutama tanggung jawab, perilaku, kerjasama dalam pembuatan administrasi daring.

Tabel Perbandingan Rata-Rata Indikator Siklus I Dan Siklus II

\begin{tabular}{|lcc|}
\hline \multicolumn{1}{r}{ Item } & Siklus I & Siklus II \\
\hline Identitas & 18 & 20 \\
\hline Tujuan & 31 & 36 \\
\hline KBM & 17 & 21 \\
\hline Penilaian & 9 & 11 \\
\hline Rata Rata & 75 & 87 \\
\hline
\end{tabular}

\section{DAFTAR PUSTAKA}

Alisyahbana, Iskandar. 1980. Teknologi dan Perkembangan. Yayasan Idayu: Jakarta

Arikunto, Suharsimi. 2010. Prosedur Penelitian Suatu Pendekatan Praktik. Jakarta: Rineka Cipta.

Anwar Prabu Mangkunegara, 2008. Manajemen Sumber Daya Manusia Perusahaan, (Bandung, PT Remaja Rosdakarya).

Daryanto, 2011 Kepala Sekolah Sebagai Pemimpin Pembelajaran, ( Yogyakarta: Gava Media).

Dirawat, 1986). Pengantar Kepemimpinan Pendidikan, (Surabaya: Usaha Nasional)

Hamka Abdul Aziz, 2012. Karakter Guru Profesional Melahirkan Murid Unggul Menjawab Tantangan Masa Depan, (Jakarta: Al-mawardi Prima).

Hanafiah, dan Cucu Suhana. 2009. Konsep Strategi Pembelajaran. Bandung: PT Refika aditama.

Hery Noer Aly dan Munzier,2000. Watak Pendidikan Islam (Jakarta: Fransiska Agung).

Jamal Ma’aruf Asmani, 2012.Tips Menjadi Kepala Sekolah Profesional, (Jogjakarta: Diva press,).

Kempa, Rudolf. 2015. Kepemimpinan Kepala Sekolah: Studi tentang Hubungan Perilaku Kepemimpinan, Keterampilan Manajerial, Manajemen Konflik, Daya Tahan Stress Kerja dengan Kinerja Guru. (Yogyakarta: Penerbit Ombak).

Kemendikbud.(2016).Permendikbud No 020 tahun 2016 Tentang Standar Kompetensi Lulusan Pendidikan Dasar Dan Menengah. Jakarta:kemendikbud.

Kompri, 2015. Manajemen Sekolah Orientasi Kemandirian Kepala Sekolah. (Yogyakarta: Pustaka Pelajar) 
Mangkunegara, Anwar Prabu, 2013. Manajemen Sumber Daya Manusia Perusahaan. (Bandung: PT Remaja Rosdakarya).

Mulyasa, E. 2011. Menjadi Kepala Sekolah Profesional. (Bandung: PT Remaja Rosdakarya).

Muwahid shulhan, 2013. Model Kepemimpinan Kepala Madrasah dalam Meningkatkan Kinerja Guru, (Yogyakarta: Teras).

Oemar Hamalik, 1983. Metode Belajar dan Kesulitan Belajar, ( Bandung: Tarsito),

Peraturan Menteri Pendidikan dan Kebudayaan Nomor 22 Tahun 2016

Peraturan Menteri Pendidikan Nasional Nomor 13 Tahun 2007 tentang Standar Kepala Sekolah/Madrasah.

Riyanto, Yatim. 2009. Paradigma Baru Pembelajaran: Sebagai Referensi Bagi Pendidikan dalam Implementasi Pembelajaran yang Efektif dan Berkualitas. Jakarta: Kencana

Siti Suwa Dahrimang, 2011.Meraih Predikat Guru dan Dosen Paripurna,(Bandung: alpabeta).

Sudarwan Danim, 2010. Inovasi Pendidikan dalam Upaya Meningkatkan Profesionalisme Tenaga Ke

pendidikan, (Bandung: Pustaka Setia).

Suprijono, Agus. 2011. Cooperative Learning. Yogyakarta: Pustaka Pelajar.

Suryantoro, 2003. Kamus Praktis, (Bandung: Ilmu).

Undang-undang No.19 Tahun 2016 tentang Perubahan Undang-undang No.11 Tahun 2008 tentang Informasi dan Transaksi Elektronik

Wahjosumijdo, 2003) Kepemimpinan Kepala Sekolah Tinjauan Teorotik dan Permasalahanya, ( Jakarta: Raja Grafindo Persada). 